\title{
THE UTILIZATION OF BLAST FURNACE WASTE.*
}

\section{By Edward M. HaGar.}

Until the last decade, practically the only utilization of the wastes or by-products of a blast furnace was the use of a portion of the waste gases to raise the temperature of the incoming blast through heating the brickwork in so-called hot stoves, and in some cases a small portion of the power value of the gases was obtained by burning them under boilers to generate steam for driving the blowing engines.

At the present time the calorific value of the waste gases is being utilized directly in gas engines for blowing purposes and for generation of electric power; a considerable portion of the slag is used in the manufacture of Portland cement, and the flue dust, consisting of the finest ore and coke particles, is being collected and converted so as to be rechargeable into the furnaces.

The aggregate saving or profits resulting from these three developments is a matter of millions of dollars per annum, and in a modern blast furnace plant, it would almost seem that pig-iron was the by-product; and, indeed, the investment in the equipment to utilize these former wastes, exceeds that of the blast furnace itself.

\section{USE OF BLAST-FURNACE GAS.}

The writer, in his work, has come in contact with these evolutions, with plants in operation, or under construction, of a capacity to produce $12,000,000$ barrels of Portland cement per annum from slag and limestone, using over $\mathbf{1}, 300,000$ tons of slag in a year, these plants being driven entirely by electric current generated by gas engines directly from the waste blast furnace gases, the power requirements being 40,000 horsepower for 24 hours every working day. In one of the cement plants the first commercial method for reclaiming the flue dust was discovered.

By using the blast furnace gases directly in combustion engines, after suitable washing to remove the grit, the power obtained from a given amount of gas is equal to at least two and one-half times that obtainable by burning the gas under boilers for generating steam for use in steam engines.

A modern blast furnace of the usual size, with gas blowing engines, and gas engines driving electric generators, will provide sufficient gas to furnish 7000 kilowatts electric power, in addition to driving its own blowing engines. This permits the most modern steel works, such as those at Gary, Ind., to practically do away with the use of coal for power purposes, operating the rolling mills by electric power from the surplus gases.

- Presented before the Congress of Technology at the fiftieth anniversary of the granting of the charter of the Massachusetts Institute of Technology, and reprinted from The Iron Trade Review, June 22, 1911 . 
FLUE DUST.

The United States Steel Corporation, of which the Universal Portland Cement Co. is a subsidiary, has already installed 250,000 horsepower of gas burning and gas electric units, which, it can easily be figured, displaces or saves the consumption of approximately a million tons of coal per annum as compared to the old-fashioned methods.

With the modern high blast pressures, and the use of fine Mesabi ore, the finest of the particles, together with the coke dust, are blown out through the top of the furnaces and are caught in the flues, dust catchers and gas washers. The iron ore in this dust amounts to fully 3 per cent. of the total ore charged, which aggregates the large amount of approximately $1,250,000$ tons per annum in this country. Until within a few years, this dust has been thrown away or used as filling, although containing about 40 per cent. metallic iron. For many years, efforts were made to use this material by compressing it into briquettes, but the cost of the operation, together with the fact that the briquettes disintegrated and the dust was again blown out, led to an abandonment of the briquetting plants.

The first commercially successful method of utilizing the dust was discovered by passing the material through the cement kilns of South Chicago. Experiments showed that with the proper heat treatment, the coke dust could be burned off and the iron ore conglomerated into nodules or nuggets averaging over 60 per cent. iron content. These nodules, when fed to the blast furnace, were easily and completely reduced. The fact that the sinter of the flue dust contains such a high percentage of iron and that all of the sinter is reduced, together with its physical shape assisting the steady movement of the charge downward in the blast furnace, thereby preventing so-called slips, makes the sinter more valuable per ton than any ore.

It was necessary to devise mechanical means for preventing the accumulation of the sinter in the walls of the kiln. Plants have been in operation for some years using this process, with endless chains carrying scrapers constantly passing forward through the kiln, and cooled in water on their return outside of the kiln. Recently other methods of utilizing dust have been devised which may prove successful commercially, and the indications are that within a short time the greater portion of this former waste will be prevented.

\section{PORTLAND CEMENT INDUSTRY.}

The development of the Portland cement industry in this country and the extension of its uses have been marvellous, and the accompanying table shows a remarkable increase in the production of Portland cement in the United States every year since I895, when this country first reached the production of approximately $1,000,000$ barrels.

It may be of interest to note the increasing percentage of the total American production shown by Universal Portland cement, which is the 
only Portland cement manufactured in this country using slag as one of the raw materials. With the new plant now approaching completion the aggregate production of Universal Portland cement in the Chicago and Pittsburg districts will amount to over one-eighth of the country's total. Expressed in weight, the output of the finished product will be over 2,000,000 gross tons per annum. Our plants in the Chicago district will consume all the available slag that is suitable for the purpose from an aggregate of 19 blast furnaces in the South Chicago works of the Illinois Steel Co. and in the Gary works of the Indiana Steel Co.

Comparing the pig-iron production and Portland cement production of this country in figures of long tons, the percentage of Portland cement to pig-iron in 1890 was six-tenths of one per cent., in 1900 I0.3 per cent. and in roro 47 per cent. The continuation of any such relative growth would mean that before I 920 the tonnage of Portland cement would considerably exceed that of pig-iron. I would hesitate, however, to predict that such would be the case.

In this country Portland cement is manufactured from a number of raw materials, which, with a few exceptions, may be classed under four heads :

First-Argillaceous limestone (cement rock) and pure limestone.

Second-Clay or shale and limestone.

Third-Clay or shale and marl.

Fourth-Slag and limestone.

In the manufacture of Portland cement from slag and limestone, the molten slag flowing from the furnaces is granulated by a stream of water, loaded into cars and transported to the cement plants, where it is dried in rotary driers, and receives the first grinding; it is then mixed in automatic weighing machines, with the proper proportion of ground and dried calcite limestone. These are then ground together and burnt to a hard clinker at a temperature of nearly 3000 degrees Fahr., rotary kilns, using pulverized coal for fuel.

This clinker, after seasoning, is crushed and ground and mixed with a small percentage of gypsum to regulate the setting time. The cement is ground to such fineness that 96 per cent. passes through a sieve having 10,000 meshes, and 80 per cent. passes a sieve with 40,000 meshes to the square inch. It is then conveyed to the stock house for storage prior to shipment.

\section{FURNACE FLUX.}

It is necessary to use as a flux in furnaces supplying slag for cement manufacture, a pure calcite limestone. The limestone burnt with the slag must also be a pure calcite stone. It is also essential that the ores used be of a uniform and proper character.

Inasmuch as Lake Superior ores are noted for their remarkable uniformity of analysis, the resultant slag obtained from the use of these ores Vol. CLXXII, No. 1028-i5 
and a pure calcite limestone, is more uniform in its analysis than any form of natural clay deposit used in the manufacture of Portland cement, and the variation in the proportions of the two raw materials used in the manufacture of Portland cement from slag is less than those of any other materials mentioned.

The rotary kiln commonly used ten years ago was 60 feet long and 6 feet in diameter. This has gradually been increased in length and diameter, until the modern kiln is 140 to $I_{50}$ feet long and 8 to ro feet in diameter, and there are a few even larger kilns in use. Kilns are usually set at an incline of three-quarters of an inch to the foot. With the lining and contents the modern kiln weighs 150 tons, and in revolving upon two bearings presents interesting constructional features.

\section{BUFFINGTON PLANT.}

In the case of the plant at Buffington, Ind., using 26,000 horsepower, situated between South Chicago and Gary, Ind., electric power is supplied at 22,000 volts from the steel works at these points. Each piece of machinery is driven by its individual motor, supplied with alternating current at 440 volts. The high tension line is connected through the cement plants, and the gas engines at these two steel works, I4 miles apart, operate continually in parallel. This enables the cement plant to draw its power from either source, or from both sources at the same time, as may be desirable. It has happened that one of these works has supplied power to operate the cement plant and furnished additional power at the same time to the steel works at the other end of the line.

True Portland cement in which slag is used as one of the raw materials, should not be confused with Puzzolan or so-called slag cements, which are simply mechanical mixtures of slag and slaked lime ground together without burning. Such cements are suitable only for use underground and in moist locations. The manufacture of Puzzolan cements in this country has practically been abandoned.

The remarkable growth of the Portland cement industry is not equalled by any other manufactured article. This is due to the economy, durability, and plasticity of cement and concrete work. While large engineering work, such as dams, bridges, and heavy reinforced concrete buildings, consume large quantities of cement, the bulk of consumption at the present day is in a multitude of small uses. It takes an average shipment of only five barrels a day to take care of the average customer of a large cement company. For example, there is a steady increase in the application of cement to new uses on the farm, such as silos, fence posts, barn floors, feeding floors, watering troughs, corn cribs, etc. There, as elsewhere, concrete is rapidly displacing all forms of wood construction, this process being hastened by the continually advancing cost of lumber. 
Cement Production of the United States.

\begin{tabular}{|c|c|c|c|}
\hline Year. & $\begin{array}{l}\text { Production } \\
\text { of Portland } \\
\text { cement of } \\
\text { United States, } \\
\text { barrels. }\end{array}$ & $\begin{array}{l}\text { Production of } \\
\text { Universal } \\
\text { Portland cement, } \\
\text { barrels. }\end{array}$ & $\begin{array}{c}\text { Percentage } \\
\text { of Universal } \\
\text { to total American } \\
\text { production of } \\
\text { Portland cement. }\end{array}$ \\
\hline I895................... & 990,324 & $\ldots \ldots$ & $\ldots$ \\
\hline I8g6................... & $I, 543,023$ & $\cdots \cdots \cdots$ & $\ldots$ \\
\hline r897 $\ldots \ldots \ldots \ldots \ldots \ldots$ & $2,677,775$ & $\ldots \ldots$ & $\ldots$ \\
\hline $1898 \ldots \ldots \ldots \ldots \ldots \ldots \ldots$ & $3,692,284$ & $\ldots \ldots$ & ... \\
\hline 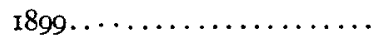 & $5,652,266$ & $\ldots \ldots \ldots$ & $\cdots$ \\
\hline I $900 \ldots \ldots \ldots \ldots \ldots \ldots$ & $8,482,020$ & 32,443 & 0.39 \\
\hline Igor $\ldots \ldots \ldots \ldots \ldots \ldots$ & $12,711,225$ & I 64,316 & 1.29 \\
\hline $1902 \ldots \ldots \ldots \ldots \ldots \ldots$ & $17,230,644$ & 318,710 & 1.85 \\
\hline $1903 \ldots \ldots \ldots \ldots \ldots \ldots \ldots$ & $22,342,973$ & 462,930 & 2.08 \\
\hline 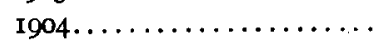 & $26,505,881$ & 473,294 & 1.78 \\
\hline $1905 \ldots \ldots \ldots \ldots \ldots \ldots \ldots$ & $35,264,812$ & $\mathrm{I}, 735,343$ & 4.92 \\
\hline Ig06 $\ldots \ldots \ldots \ldots \ldots \ldots \ldots$ & $46,463,424$ & $2,076,000$ & 4.55 \\
\hline $1907 \ldots \ldots \ldots \ldots \ldots \ldots$ & $48,785,390$ & $2,129,000$ & $4 \cdot 36$ \\
\hline $1908 \ldots \ldots \ldots \ldots \ldots \ldots$ & $51,072,612$ & $4,535,000$ & 8.89 \\
\hline I909.................. & $62,508,46 \mathrm{I}$ & $5,786,000$ & 9.27 \\
\hline rgro..................... & $73,500,000^{*}$ & $7,001,500$ & 9.52 \\
\hline
\end{tabular}

\section{BOOK NOTICE.}

Leçons Sur L'ÉlectrictTé, Professées a l'Institut Electrotechnique Montefiore. Par Eric Gerard, Directeur de cet Institut. Eighth edition, entirely reset, two volumes, paper covers. Vol. I.-Elements of Electricity and Magnetism, Electrometry, Theory and Construction of Electric Generators, xii, 975 pages, $91 / 2 \times 6 \frac{1}{2} 2$ inches with $45^{8}$ figures. Price 12 francs. Vol. II. -Transformers, Transmission Lines and the Distribution of Electrical Energy. Applications to telegraphy and telephony, to lighting, to the production and transmission of motive power, to traction, to metallurgy and to industrial chemistry. 990 pages, $91 / 2 \times 6 \frac{1}{2}$ inches with 489 figures. Price I2 Francs. Gauthier-Villars, Paris, 1910.

The distinguished author of this voluminous treatise needs no introduction to American readers, an early edition having been translated into English in 1897. Since that time, it is evident that the growth of the work has not suffered from neglect in keeping abreast with the constantly increasing scope and elaboration of the subject. Covering the entire field of electrical engineering, that the work is not even more voluminous speaks highly for the discrimination shown in treating the component topics.

The work combines the desirable qualities of the analytic method of the physicist with the material procedure of the engineer. Fundamentals are treated at length and, without attempting to exhaust any one particular department, each is treated with a degree of thoroughness only excelled in special monographs. As is already well known the author's presentation is at once precise and lucid and even the student who knows only "college" French, will find profit in keeping it readily accessible. 